\title{
PENGARUH WaG (WHATSAPP GROUP) TERHADAP KEMAMPUAN PEMAHAMAN MATEMATIS SISWA SMP NEGERI 4 PEKALONGAN
}

\author{
Dewi Azizah 1), Amalia Fitri ${ }^{2)}$ \\ ${ }^{1,2}$ Fakultas Keguruan dan Ilmu Pendidikan, Universitas Pekalongan \\ Email: ${ }^{1}$ azizah.0186@gmail.com , ${ }^{2}$ fitriamalia280186@ gmail.com
}

\begin{abstract}
The spread of the Covid-19 virus has resulted in learning to be carried out online. The use of learning media is one of the solutions used by teachers in delivering material. The media used in this study were worksheets and learning videos. The media can help students in making it easier to understand the material given by the teacher. In addition, the media can foster student interest in learning, so that students' mathematical understanding abilities become better. This study aims to describe the application of WaG to students' mathematical understanding abilities. This research is an experimental research. The population of this study was the eighth grade students of SMP Negeri 4 Pekalongan which consisted of 7 classes. The sampling technique was done by random sampling. Data collection techniques through tests. Data were analyzed using t test through SPSS. The results of this study indicate that WaG learning assisted by worksheets and learning videos produces better mathematical understanding abilities than task-based WaG learning.
\end{abstract}

Keywords: WaG, mathematical understanding abilities, worksheets, learning videos

\section{PENDAHULUAN}

Merujuk pada penyebaran virus Covid-19 di pertengahan bulan Maret 2020 di Indonesia mengakibatkan terjadinya perubahan kebijakan dalam dunia pendidikan. Kebijakan tersebut dikeluarkan melalui Surat Edaran Mendikbud No. 4 Tahun 2020 yaitu tentang Pelaksanaan Kebijakan Pendidikan dalam Masa Darurat Penyebaran Coronavirus Disease (Covid-19). Salah satu kebijakan yang ditetapkan yaitu merubah cara belajar mengajar melalui pembelajaran daring. Begitu pula pembelajaran di SMP Negeri 4 Pekalongan menetapkan proses belajar mengajar dilakukan secara daring. Berdasarkan wawancara dengan salah satu guru matematika, pembelajaran daring yang dilakukan yaitu melalui Whatsapp Group $(W a G)$ berbasis tugas. Penggunaan $W a G$ ini dirasa oleh guru sebagai media yang sudah terbiasa siswa gunakan tanpa perlu adanya sosialisasi dalam penggunaanya.

Pertama kali penggunaan $W a G$ berbasis tugas di SMP Negeri 4 Pekalongan, siswa masih antusias mengikuti pelajaran. Hal ini dilihat dari seluruh siswa yang aktif berdiskusi dan mau mengumpulkan tugas melalui $W a G$. Namun, pembelajaran daring berikutnya nampak berbeda, siswa yang berpartisipasi dalam kegiatan diskusi $W a G$ semakin menurun. Selain itu, tugas yang terkumpul hanya siswa tertentu yang memiliki kemampuan kognitif tinggi. Padahal guru memberikan kelonggaran waktu dalam mengumpulkan tugas sekitar 3-4 hari.

Beberapa siswa di SMP tersebut merasa bosan jika pembelajaran melalui $W a G$ hanya dengan pemberian materi yang dikirim berupa $p d f$ dan dilanjutkan pemberian soal-soal atau tugas. Selain itu, siswa tidak diberikan kesempatan untuk konfirmasi lebih lanjut terkait materi yang telah diberikan. Bagi siswa yang berkemampuan tinggi masih bisa mencari referensi dari internet atau sumber lain, tetapi berbeda dengan siswa yang memiliki kemampuan di bawah rata-rata semakin acuh dengan pembalajaran. Keadaan seperti ini jika dibiarkan terus menerus dapat mengakibatkan kesalahpahaman siswa dalam menangkap konsep pada materi yang telah diberikan. Pendapat Wahyono, et al (2020) menyatakan 
guru tidak boleh semata-mata memberikan tugas, tetapi harus memperhitungkan secara matang. Guru tidak boleh lupa mengapresiasi capaian siswa. Kurikulum yang fleksibel dan siap menghadapi pandemi juga dibutuhkan.

Pembelajaran daring yang kurang menarik dapat mengakibatkan siswa bosan dalam mengikutinya. Sebagian siswa hanya terpaksa mengikuti dan mengerjakan tugas yang diberikan. Oleh karena itu, agar pembelajaran daring tidak membosankan bagi siswa, yang dilakukan oleh guru bukan hanya dengan pemberian tugas. Tetapi perlu diperlukan strategi khusus yaitu dengan mengemas pembelajaran agar menarik, baik untuk dipelajari maupun dikerjakan oleh siswa.

Media pembelajaran mempunyai peranan penting dalam meningkatkan kemampuan minat belajar siswa. Penggunaan media pembelajaran yang menarik dapat membangkitkan keinginan dan minat siswa dalam mempelajari matematika, seperti yang dijelaskan oleh Hamlik dalam Arsyad (dalam Dhitayana, 2016:7) bahwa penggunaan media pembelajaran dalam proses belajar mengajar dapat membangkitkan keinginan dan minat baru, membangkitkan motivasi belajar, dan bahkan membawa pengaruh-pengaruh psikologis terhadap siswa. dengan tumbuhnya minat belajar siswa, diharapkan mampu menghasilkan kemampuan pemahaman matematis yang baik.

Salah satu solusi yang bisa diterapkan yaitu dengan menerapkankan pembelajaran melalui $W a G$ berbantuan LKS dan video pembelajaran. Dalam penelitian ini, peneliti memilih pembelajaran daring melalui $W a G$ karena berbagai pertimbangan seperti, kondisi dan kesiapan siswa dalam mengikuti pembelajaran daring, akses internet, kuota internet serta perangkat smartphone yang dimiliki siswa menjadi salah satu pertimbangan diterapkannya pembelajaran ini. Dengan demikian peneliti menilai bahwa pembelajaran melalui $W a G$ cocok untuk diterapkan.

Menurut Bohang dalam Sutrisno (2019) menyatakan bahwa CEO Facebook, Mark Zuckerberg melaporkan perfoma bisnis perusahaan-perusahaannya untuk kuartal empat 2017. Layanan Chatting Whatsapp menunjukkan pertumbuhan signifikansi dengan menghimpun 1,5 miliar pengguna aktif bulanan. Sejalan dengan pendapat tersebut, pembelajaran melalui $W a G$ dilakukan sebagai inovasi pembelajaran agar siswa tertarik dengan pembelajaran matematika. Sehingga minat belajar siswa terhadap matematika juga dapat meningkat. Bagi siswa SMP Negeri 4 Pekalongan, pembelajaran daring ini merupakan pengalaman baru yang sebelumnya belum pernah diterapkan. Jadi peneliti berupaya agar siswa lebih tertarik untuk mengikuti pembelajaran, yaitu dengan memberikan reward berupa kuota gratis.

Peneliti mengambil pembelajaran melalui $W a G$ berbantuan LKS dikarenakan penggunaan LKS dalam pelaksanaan pembelajaran dapat memudahkan guru dalam mengajar. Dengan adanya LKS, siswa menjadi lebih aktif mengolah materi maupun mencari solusi dari permasalahan yang diberikan, sehingga dapat dikatakan dapat meminimkan peran guru, terlebih melihat kondisi di tengah pandemi ini yang mengharuskan pembelajaran jarak jauh. Di dalam LKS memuat soal-soal yang memberikan kesempatan kepada siswa untuk dapat mengasah kemampuannya melalui pengalaman yang mereka peroleh sebelumnya. Siswa juga dapat lebih aktif dalam menuangkan ide-ide yang dimilikinya, sehingga diharapkan siswa dapat memperoleh kemampuan pemahaman matematis yang lebih baik. Hal ini sejalan dengan penelitian yang dilakukan oleh Annajmi dan Azmi (2017) menunjukkan hasil bahwa penggunaan LKS berbasis metode penemuan terbimbing dapat meningkatkan kemampuan pemahaman konsep matematika siswa.

Selain LKS, video pembelajaran juga digunakan dalam penelitian ini. Dengan adanya video, siswa dapat memutar ulang sesuai sejauh mana pemahaman siswa terhadap materi. Media pembelajaran berupa video memiliki beberapa keunggulan. Beberapa keunggulan menurut Majid dalam Nurdin et.al (2019), yaitu menciptakan kemandirian belajar, komunikatif dan dapat diulang, menampilkan sesuatu dengan detail dan kompleks, dapat diulang, diperlambat, bahkan diperbesar. Dengan demikian, pembelajaran menjadi lebih menarik, 
tidak monoton, dan tidak membosankan, sehingga menjadi daya tarik yang diminati oleh siswa. Jika siswa memiliki minat terhadap belajar matematika, maka diharapkan siswa dapat memiliki pemahaman matematis yang baik. Sejalan dengan hasil penelitian dari Gusmania dan Wulandari (2018) menunjukkan bahwa penggunaan media pembelajaran berupa video dapat meningkatkan kemampuan pemahaman konsep matematis siswa. Penelitian ini dapat berjalan efektif jika media yang digunakan guru tepat dan sesuai dengan keadaan siswa. Tujuan dari penelitian ini untuk mendeskripsikan pembelajaran $\mathrm{WaG}$ berbantuan LKS dan video pembelajaran menghasilkan kemampuan pemahaman matematis lebih baik daripada dengan pembelajaran $\mathrm{WaG}$ berbasis tugas.

\section{METODE PENELITIAN}

Penelitian ini dilaksanakan di kelas VIII SMP Negeri 4 Pekalongan tahun ajaran 2019/2020. Penelitian ini merupakan penelitian kuantitatif dengan metode eksperimen. Desain yang digunakan yaitu quasi experimental dengan bentuk the nonequivalent posttest-only control design. Proses penelitian ini bersifat deduktif, di mana untuk menjawab rumusan masalah digunakan konsep atau teori sehingga dapat dirumuskan hipotesis. Rumusan hipotesis pada penelitian ini yaitu $\mathrm{H}_{\mathrm{o}}$ : pembelajaran $W a G$ berbantuan LKS dan video pembelajaran menghasilkan kemampuan pemahaman matematis lebih baik daripada dengan pembelajaran $W a G$ berbasis tugas; dan $\mathrm{H}_{1}$ : pembelajaran $W a G$ berbantuan LKS dan video pembelajaran menghasilkan kemampuan pemahaman matematis tidak lebih baik dari pembelajaran $W a G$ berbasis tugas.

Teknik pengambilan sampel dilakukan dengan menggunakan random sampling. Teknik ini dilakukan karena anggota populasi yang ada telah dikelompokkan berdasarkan kelas. Sampel yang diambil yaitu kelas VIII B sebagai kelas eksperimen dan kelas VIII A sebagai kelas kontrol.

Teknik pengumpulan data yang digunakan yaitu tes. Tes berbentuk uraian untuk mengumpulkan data kemampuan pemahaman matematis. Sebelum diberikan perlakuan, tes diujicobakan pada kelas uji coba untuk melihat kriteria tes tersebut valid, reliable, tingkat kesukaran sedang, dan daya pembeda baik.

Data awal dianalisis dari hasil Penilaian Akhir Semester (PAS) semester ganjil baik dari kelas VIII B maupun VIII A. Analisis data awal yang digunakan yaitu uji normalitas, uji homogenitas dan uji beda rerata. Analisis tersebut digunakan sebagai uji prasyarat untuk melihat kemampuan kedua kelas tersebut dalam keadaan sama. Kemudian, kedua kelas eksperimen dan kontrol diberikan perlakuan.

Kelas ekperimen mendapat perlakuan menggunakan pembelajaran $W a G$ berbantuan LKS dan Video Pembelajaran, sedangkan kelas kontrol mendapat perlakuan menggunakan pembelajaran $W a G$ berbasis tugas. Setelah diberikan perlakuan, kedua kelas tersebut masing-masing diberikan tes sebagai data akhir. Data akhir yang telah terkumpul dianalisis menggunakan uji t melalui SPSS.

\section{HASIL DAN PEMBAHASAN}

Kelas eksperimen dan kontrol diberikan perlakuan menggunakan pembelajaran $W a G$ tetapi dengan bantuan media pembelajaran yang berbeda. Kelas eksperimen menggunakan media LKS dan video pembelajaran, dan kelas kontrol melalui tugas dalam bentuk file atau foto materi dari buku pelajaran. Media pembelajaran yang digunakan guru di kelas kontrol tersebut merupakan media yang digunakan di masa pandemi saat ini. Hal ini melihat dari kondisi dan kesiapan siswa untuk mengikuti pembelajaran daring yang merupakan mungkin pengalaman pertama bagi beberapa siswa. Akses internet, kuota internet serta perangkat smartphone yang dimiliki siswa juga menjadi pertimbangan diterapkannya pembelajaran ini, dengan demikian pembelajaran E-Learning melalui $W a G$ dirasa cocok untuk diterapkan di kelas eksperimen maupun kontrol, tetapi dengan strategi yang berbeda.

Penelitian dilakukan sebanyak 3 (tiga) kali pertemuan, baik di kelas eksperimen maupun kelas kontrol. Dilanjutkan dengan pemberian tes kemampuan pemahaman matematis yang dijadikan sebagai post test. Hasil post test tersebut sebagai data akhir yang dianalisis 
untuk membuktikan kebenaran hipotesis penelitian.

Tes yang digunakan dalam penelitian ini berupa soal uraian yang telah diujicobakan dan dianalisis. Soal tersebut digunakan baik di kelas eksperimen maupun kelas kontrol untuk mengukur kemampuan pemahaman matematis dengan empat indikator menurut Lestari dan Yudhanegara (2017:81) yaitu : mengidentifikasi dan membuat contoh dan bukan contoh; menerjemahkan dan menafsirkan makna simbol, tabel, diagram, gambar, grafik, serta kalimat matematis; memahami dan menerapkan ide matematis; dan membuat suatu ekstrapolasi (perkiraan). Dari masing-masing indikator dianalisis rata-rata skornya untuk melihat pada indikator mana siswa mampu menyelesaikan persoalan dengan baik. Menurut hasil penelitian Rahmi, Irwan, dan Mirna (2018), menyatakan bahwa semakin tinggi rata-rata skor setiap indikator, artinya semakin banyak siswa yang memberikan jawaban dengan baik. Rata-rata skor untuk masing-masing indikator nampak pada tabel berikut.

Tabel 1 Rata-rata Skor Indikator Kemampuan Pemahaman Matematis

\begin{tabular}{ccccc}
\hline \multirow{2}{*}{ Kelas } & \multicolumn{4}{c}{ Indikator } \\
\cline { 2 - 5 } & 1 & 2 & 3 & 4 \\
\hline Eksperimen & 3,47 & 3,03 & 3,10 & 2,33 \\
Kontrol & 3,20 & 3,10 & 2,73 & 1,77 \\
\hline
\end{tabular}

Dari tabel 1 menunjukkan bahwa rata-rata skor pada indikator 1,3 , dan 4 di kelas eksperimen lebih tinggi dibanding kelas kontrol. Tetapi pada indikator 2, nampak ratarata skor indikatornya lebih baik di kelas kontrol. Hal ini terjadi karena pada indikator tersebut banyak siswa yang salah dalam menerjemahkan dan menafsirkan makna simbol, tabel, diagram, gambar, grafik, serta kalimat matematis. Setelah rata-rata skor dianalisis, kemudian dilakukan analisis data untuk melihat apakah pembelajaran $W a G$ berbantuan LKS dan video pembelajaran menghasilkan kemampuan pemahaman matematis lebih baik daripada dengan pembelajaran $W a G$ berbasis tugas.

Analisis data untuk pengujian hipotesis dianalisis dari hasil tes kemampuan pemahaman konsep dua sampel yaitu kelas eksperimen dan kontrol. Sebelum data dianalisis, uji prasyarat yang harus dipenuhi yaitu data harus normal dan homogen. Berdasarkan hasil analisis dengan SPSS yaitu melalui uji KolmogorovSmirnov diperoleh hasil signifikansi 0,094 > 0,05 , artinya data pada sampel berdistribusi normal seperti tabel berikut.

Tabel 2 Hasil Uji Normalitas Data

\begin{tabular}{cccc}
\hline & \multicolumn{3}{c}{ Kolmogorov-Smirnov $^{\mathrm{a}}$} \\
\cline { 2 - 4 } Nilai & Statistic & Df & Sig. \\
\hline a. & .106 & 60 & .094 \\
\hline
\end{tabular}

a. Lilliefors Significance Correction

Selanjutnya, untuk menguji apakah variansi dari kedua sampel tersebut sama (homogen) dengan SPSS menggunakan uji Levene diperoleh hasil signifikansi $0,061>0,05$ artinya data homogen. Seperti hasil dari SPSS berikut ini.

Tabel 3 Hasil Uji Homogenitas

\begin{tabular}{lccccc}
\hline & $\begin{array}{c}\text { Levene } \\
\text { Statistic }\end{array}$ & df1 & df2 & Sig. \\
\hline $\begin{array}{l}\text { Based on } \\
\text { Mean }\end{array}$ & 3.649 & 1 & 58 & .061 \\
$\begin{array}{l}\text { Based on } \\
\text { Median }\end{array}$ & 2.663 & 1 & 58 & .108 \\
$\begin{array}{l}\text { Based on } \\
\text { Median and } \\
\text { with } \\
\text { adjusted df } \\
\text { Based on } \\
\text { trimmed } \\
\text { mean }\end{array}$ & 2.663 & 1 & 54.405 & .108 \\
\hline
\end{tabular}

Jika kedua prasyarat data normal dan homogen sudah terpenuhi, maka statistik uji untuk menguji hipotesis dilakukan dengan uji t melalui SPSS. Dari hasil perhitungannya diperoleh bahwa hasil signifikansi 0,048 $<0,05$ artinya $\mathrm{H}_{\mathrm{o}}$ ditolak yang berarti kemampuan pemahaman matematis siswa yang diajar dengan $W a G$ berbantuan LKS dan video pembelajaran lebih baik daripada $W a G$ berbasis tugas. Hal ini dikarenakan pembelajaran dengan menggunakan pembelajaran $W a G$ berbantuan LKS dan video pembelajaran, siswa dituntut untuk mengingat materi dasar dengan mejawab beberapa soal yang ada di LKS, selain itu juga penggunaan video pembelajaran untuk memperkuat penjelasan yang sudah guru berikan dalam WaG. Pemahaman siswa dipantau dengan adanya LKS, dan dengan adanya video pembelajaran siswa dapat 
mengulang kembali penjelasan guru sehingga dapat memahami materi dengan baik. Dalam pembelajaran ini, guru menjanjikan reward berupa kuota gratis bagi siswa yang aktif dan sering menjawab pertanyaan pada saat pembelajaran, sehingga siswa lebih bersemangat untuk mengikuti pembelajaran daring tersebut. Seperti yang dijelaskan oleh Hamlik dalam Arsyad (dalam Dhitayana, 2016:7) bahwa penggunaan media pembelajaran dalam proses belajar mengajar dapat membangkitkan keinginan dan minat baru, membangkitkan motivasi dan rangsangan kegiatan belajar, dan bahkan membawa pengaruh-pengaruh psikologis terhadap siswa. Dengan demikian, mampu menghasilkan kemampuan pemahaman matematis yang baik.

\section{SIMPULAN DAN SARAN}

\subsection{Simpulan}

Berdasarkan hasil penelitian dan pembahasan, maka dapat disimpulkan bahwa pembelajaran $W a G$ berbantuan LKS dan video pembelajaran menghasilkan kemampuan pemahaman matematis lebih baik daripada dengan pembelajaran $W a G$ berbasis tugas.

\subsection{Saran}

Saran yang diberikan yaitu: penggunaan $W a G$ berbantuan LKS dan video pembelajaran sebagai salah satu solusi media pembelajaran daring oleh guru-guru di Kota Pekalongan dengan materi yang berbeda; (2) penggunaan $W a G$ berbantuan LKS dan video pembelajaran dapat digunakan untuk mengukur kemampuan kognitif siswa di Kota Pekalongan selain kemampuan pemahaman matematis; (3) guru-guru di kota Pekalongan dapat berinovasi mengembangkan media pembelajaran selain LKS dan video pembelajaran.

\section{REFERENSI}

Annajmi dan Azmi Asra. 2017. "Pengembangan Lembar Kegiatan Siswa (LKS) Berbasis Metode penemuan Terbimbing untuk Meningkatkan Kemampuan Pemahaman Konsep Matematika Siswa Kelas VII SMP Islam Kepenuhan Kabupaten Rokan Hulu". Jurnal Eksata Pendidikan (JEP). Vol.1, No.1 Mei 2017.
Dhitayana, Oktav Rivinograha. 2016. Pembelajaran Matematika dengan Media Komik untuk Meningkatkan Minat Belajar Siswa Kelas VIII SMP YBPK Wonoasri. Skripsi, tidak diterbitkan, UNP Kediri.

Gusmania, Yesi dan Tri Wulandari. 2018. "Efektivitas Penggunaan Media Pembelajaran Berbasis Video Terhadap Pemahaman Konsep Matematis Siswa". PYTHAGORAS. Vol. 7 No. 1 halaman 61-67.

Lestari, Kurnia Eka, dan Mohammad Ridwan Yudhanegara. 2017. Penelitian Pendidikan Matematika. Bandung : Refika Aditama.

Nurdin, Erdawati., Aulia Ma'ruf, Zubaidah Amir, Risnawati, Noviarni, Memen Permata Azmi. 2019."Pemanfaatan Video Pembelajaran Berbasis Geogebra untuk Meningkatkan Kemampuan Pemahaman Konsep Matematis Siswa SMK". Jurnal Riset Pendidikan Matematika. Vol. 6, No. 1, 87-98.

Rahmi, Latifa., Irwan, dan Mirna. 2018. Pengaruh Pembelajaran Master Terhadap Kemampuan Pemahaman Konsep Matematika Siswa. Jurnal Pendidikan Matematika. Vol. 7, No. 1, 93-99.

Sutrisno, Eko. 2019. "Penerapan Media Sosial Whatsapp untuk Meningkatkan Minat dan Hasil Belajar Siswa SMK Komputama Majenang Pada Pembelajaran Persamaan Kuadrat". Prosiding Seminar Nasional \& Call For Papers. Program Studi Magistr Pendidikan Matematika, Universitas Siliwangi.

Wahyono, Pancojari., H. Husamah, Anton Setia Budi. 2020. "Guru profesional di masa pandemi COVID-19: Review implementasi, tantangan, dan solusi pembelajaran daring". Jurnal Pendidikan Profesi Guru. Vol.1 No.1. 